\title{
PERANCANGAN SISTEM INFORMASI REKAM MEDIS BERBASIS WEB (STUDI KASUS DI KLINIK BERSALIN SRIATI KOTA SUNGAI PENUH - JAMBI)
}

\author{
Tiara Handayani ${ }^{1)}$, Gerson Feoh ${ }^{2)}$ \\ Prodi Perekam Dan Informasi Kesehatan ${ }^{1)}$ Prodi Teknik Informatika ${ }^{2)}$ \\ Universitas Dhyana Pura, Badung, Bali \\ Tiarahandayani1@gmail.com ${ }^{1)}$ jcxome@gmail.com ${ }^{2)}$
}

\begin{abstract}
The records officer at Maternity Clinic Sriati Sungai Penuh - Jambi in its management and reporting of patient data are still using manual systems. It has caused a delay in the delivery of information and report on daily data patients. Thus, it needs a system of web-based medical record information that can assist officers in the medical record of the patient data management processing. This system design method uses development life cycle (Systems Development Life Cycle-SDLC) which consists of planning, analysis, design, implementation, and use. Meanwhile, the purpose and benefits of the design of this information system is to produce a system of webbased medical record information in Maternity Clinic Sriati River Sungai Penuh - Jambi. With this information system, it eases medical records clerk in the management of patient data whichh includes patient registration process, the recording of patient medical records, physician data recording, data recording space, the search code ICD 9 CM and ICD code search 10. In addition, this information system produces a variety of reports and patient medical record information that is required for management decision making.
\end{abstract}

Keywords: Information Systems, Medical Record, Maternity Clinic, Web.

\begin{abstract}
ABSTRAK
Petugas rekam medis di Klinik Bersalin Sriati Kota Sungai Penuh - Jambi dalam pengelolaan dan pembuatan laporan data pasien masih menggunakan sistem manual. Hal ini menyebabkan terjadinya keterlambatan dalam penyampaian informasi dan pelaporan data harian pasien. Maka diperlukan sebuah sistem informasi rekam medis berbasis web yang dapat membantu petugas rekam medis dalam proses pengelolaan data pasien tersebut. Metode perancangan sistem ini menggunakan siklus hidup pengembangan sistem (Systems Development Life Cycle-SDLC) yang terdiri dari tahap perencanaan, analisis, desain, implementasi, dan penggunaan. Sedangkan tujuan dan manfaat dari perancangan sistem informasi ini yaitu menghasilkan sebuah sistem informasi rekam medis berbasis web di Klinik Bersalin Sriati Kota Sungai Penuh - Jambi. Dengan adanya sistem informasi ini, dapat memudahkan petugas rekam medis dalam pengelolaan data pasien yang meliputi proses pendaftaran pasien, pencatatan rekam medis pasien, pencatatan data dokter, pencatatan data ruang, pencarian kode ICD 9 CM, dan pencarian kode ICD 10. Selain itu sistem informasi ini menghasilkan berbagai laporan-laporan serta informasi rekam medis pasien yang dibutuhkan pihak manajemen untuk pengambilan keputusan.
\end{abstract}

Kata kunci: Sistem Informasi, Klinik Bersalin, ICD 9 CM, ICD 10 


\section{PENDAHULUAN}

Perkembangan teknologi informasi yang begitu pesat telah merambah ke berbagai sektor, termasuk kesehatan. Teknologi informasi memiliki potensi dalam memproses data dan mengolahnya menjadi informasi, teknologi informasi mampu menyimpan data dengan jumlah kapasitas lebih banyak. Teknologi informasi juga memungkinkan data kesehatan dikirim secara mudah dan cepat. Perkembangan teknologi informasi sangat mendukung dalam manajemen rekam medis secara lebih efektif dan efisien.

Upaya meningkatkan pelayanan kesehatan terutama di klinik bersalin sangat dibutuhkan, oleh karena itu diperlukannya suatu sistem terkomputerisasi untuk dapat meningkatkan pelayanan serta dapat menunjang kegiatan - kegiatan klinik bersalin seperti pengolahan data dan pelaporan data pasien.

Klinik Bersalin Sriati adalah salah satu klinik bersalin yang berada di wilayah Pelayang raya Kota Sungai Penuh Jambi, yang melayani pemeriksaan ibu hamil, proses persalinan, pemasangan alat kontrasepsi dan imunisasi bagi balita. Rata-rata kunjungan pasien perhari adalah 20 sampai 30 pasien rawat jalan dan rawat inap dengan 7 kamar dan 10 tempat tidur.

Dalam pengolahan dan pembuatan laporan data pasien di Klinik Bersalin Sriati masih menggunakan sistem manual.

Hal ini menyebabkan terjadinya keterlambatan dalam penyampaian informasi pelaporan data harian pasien. Untuk mengatasi masalah ini diperlukan adanya pengembangan sistem dengan tingkat perhitungan dan penyampaian datanya lebih cepat, mampu bekerja cepat dan lebih akurat. Dengan adanya sistem ini dapat membantu petugas rekam medis di Klinik Bersalin Sriati dalam mempercepat dan mempermudah proses pengelolaan data pasien dan mengurangi antrian pada pasien rawat jalan. Dengan menggunakan sistem manual waktu yang diperlukan untuk pendaftaran pasien adalah 8 sampai 10 menit.

\section{TINJAUAN PUSTAKA}

\section{Pengertian Rumah Sakit}

Rumah Sakit adalah institusi pelayanan kesehatan yang menyelenggarakan pelayanan kesehatan perorangan secara paripurna yang menyediakan pelayanan rawat inap, rawat jalan, dan gawat darurat. Rumah Sakit Umum adalah rumah sakit yang memberikan pelayanan kesehatan pada semua bidang dan jenis penyakit. Rumah Sakit Khusus adalah rumah sakit yang memberikan pelayanan utama pada satu bidang atau satu jenis penyakit tertentu berdasarkan disiplin ilmu, golongan umur, organ, jenis penyakit atau kekhususan lainnya. Rumah Sakit Publik adalah rumah sakit yang dikelola oleh Pemerintah, Pemerintah Daerah dan Badan Hukum yang bersifat nirlaba. Rumah Sakit Privat adalah rumah sakit yang dikelola oleh badan hukum dengan tujuan profit yang berbentuk perseroan terbatas atau persero (Permenkes No. 147 tahun 2010). Rumah sakit merupakan suatu institusi pelayanan kesehatan yang menyelenggarakan pelayanan kesehatan perorangan secara paripurna yang menyediakan pelayanan rawat inap, rawat jalan dan gawat darurat (UU RI No. 44 tahun 2009).

Dari sumber di atas dapat disimpulkan bahwa rumah sakit adalah suatu institusi pelayanan kesehatan yang menyelenggarakan pelayanan kesehatan perorangan secara paripurna yang menyediakan pelayanan rawat inap, rawat jalan, dan gawat darurat. Menurut jenis pelayanannya rumah sakit di bagi atas 2 kelompok yaitu Rumah Sakit Umum dan Rumah Sakit Khusus. Rumah Sakit Umum memberikan pelayanan kesehatan pada semua bidang dan jenis penyakit, sedangkan Rumah Sakit Khusus memberikan pelayanan utama pada satu bidang atau satu jenis penyakit tertentu berdasarkan disiplin ilmu, golongan umur, organ, jenis penyakit atau kekhususan lainnya. 


\section{Pengertian Rekam Medis}

Rekam Medis adalah berkas yang berisikan catatan dan dokumen tentang identitas pasien, pemeriksaan, pengobatan, tindakan, dan pelayanan yang telah diberikan kepada pasien. Catatan merupakan tulisantulisan yang dibuat oleh dokter atau dokter gigi mengenai tindakan-tindakan yang dilakukan kepada pasien dalam rangka pelayanan kesehatan. Sedangkan dokumen adalah catatan dokter, dokter gigi, dan atau tenaga kesehatan tertentu, laporan hasil pemeriksaan penunjang, catatan observasi dan pengobatan harian dan semua rekaman, baik berupa foto radiologi, gambar pencitraan (imaging) dan rekaman elektrodiagnostik, sehingga rekam medis harus dibuat secara tertulis, lengkap dan jelas dan dalam bentuk teknologi Informasi elektronik yang diatur lebih lanjut dengan peraturan tersendiri (Permenkes No.269/Menkes/Per/III/2008).

Bagian akademik sekolah adalah bagian yang membuat dan mengatur arsip arsip yang berkaitan dengan data siswa, guru, rencana kegiatan belajar mengajar dan pencatatan nilai siswa yang kemudian dijadikan bahan pelaporan kepada pihak-pihak yang memerlukan, antara lain : siswa, orang tua / wali siswa, kepala sekolah, yayasan, dan dinas pendidikan setempat. Data yang akan diolah meliputi : Data Guru, Data Siswa, Mata Pelajaran.

\section{Pengertian Klinik}

Klinik adalah fasilitas pelayanan kesehatan yang menyelenggarakan pelayanan kesehatan perorangan yang menyediakan pelayanan medis dasar dan atau spesialistik, diselenggarakan oleh lebih dari satu jenis tenaga kesehatan dan dipimpin oleh seorang tenaga medis. Tenaga medis adalah dokter, dokter spesialis, dokter kandungan atau dokter kandungan spesialis, sedangkan tenaga kesehatan adalah setiap orang yang mengabdikan diri dalam bidang kesehatan serta memiliki pengetahuan dan atau keterampilan melalui pendidikan di bidang kesehatan yang untuk jenis tertentu memerlukan kewenangan untuk melakukan upaya kesehatan (Permenkes 028/Menkes/ Per/I/2011).

\section{Profil Klinik Bersalin}

Klinik Bersalin Sriati berdiri pada tahun 2012, klinik ini didirikan oleh dr. Dedi hendri, S.pog dan Bidan Sriati Amd,Keb dengan nomor izin 441/05.6/II.3/Dinkes, dengan rata-rata kunjungan pasien rawat jalan dan rawat inap adalah 20-30 pasien perhari. Klinik Bersalin Sriati terletak di jalan Soekarno Hatta No.50 Pelayang Raya Kota Sungai Penuh Jambi. Klinik Bersalin ini memiliki 7 kamar dan 10 tempat tidur.

Klinik Bersalin Sriati masih menggunakan sistem manual pada registrasi pasien dan juga dalam pengelolaan data pasien, hal ini menyebabkan terjadinya antrian pasien rawat jalan pada saat registrasi, dimana untuk satu registrasi pasien rawat jalan menghabiskan waktu 8 sampai 10 menit. Dengan menggunakan sistem manual penyampaian informasi dan pelaporan data harian pasien akan menjadi terlambat.

\section{Sistem Informasi}

Sistem adalah sekumpulan unsur yang berhubungan antara satu dengan yang lainnya sedemikian rupa berproses mencapai tujuan tertentu, atau suatu tatanan dimana terjadi suatu kesatuan dari berbagai unsur yang saling berkaitan secara teratur menuju pencapaian unsur dalam batas lingkungan tertentu (Ery Rustiyanto, 2010).

Informasi merupakan salah satu sumber daya penting dalam suatu organisasi, digunakan sebagai bahan pengambilan keputusan. Sehubungan dengan hal itu, informasi haruslah berkualitas. Kualitas informasi ditentukan oleh tiga faktor, yaitu relevansi, tepat waktu, dan akurasi. Relevansi berarti bahwa informasi benar-benar berguna bagi suatu tindakan keputusan yang dilakukan oleh seseorang. Tepat waktu berarti bahwa informasi datang pada saat dibutuhkan sehingga bermanfaat untuk pengambilan keputusan.

Sistem informasi merupakan sekumpulan hardware, software, brainware, prosedur dan aturan yang diorganisasikan 
secara integral untuk mengolah data menjadi informasi yang bermanfaat guna memecahkan masalah dan pengambilan keputusan. Sistem informasi adalah sebuah sistem manusia atau mesin yang terpadu (integrated) untuk menyajikan informasi guna mendukung fungsi operasi, manajemen, dan pengambilan keputusan dalam sebuah organisasi. Sistem informasi merupakan kesatuan elemen-elemen yang saling berinteraksi secara sistematis dan teratur untuk menciptakan dan membentuk aliran informasi yang akan mendukung pembuatan keputusan dan melakukan kontrol terhadap jalannya suatu organisasi / institusi (Raymond McLeod, Jr., George P.Schell, 2008).

\section{Sistem Informasi Kesehatan (SIK)}

Sistem informasi kesehatan (SIK) merupakan suatu sistem informasi yang terdiri dari data, manusia, dan proses, serta kombinasi dari perangkat keras, perangkat lunak dan teknologi komunikasi atau yang dikenal dengan teknologi informasi. Penggunaan sistem informasi terlibat dalam tiga tahap yaitu pemasukan data, pemrosesan, dan pengeluaran informasi. Tahap pemasukan data menggunakan formulir data atau lembar data yang bisa jadi belum memiliki arti. Maka sistem kemudian akan mengolah data ini menjadi informasi yang lebih berarti (Gemala R.Hatta, 2012).

Sistem informasi kesehatan (SIK) adalah suatu sistem yang menyediakan dukungan informasi bagi proses pengambilan keputusan di setiap jenjang administrasi kesehatan, baik di tingkat unit pelaksana upaya kesehatan, di tingkat kabupaten dan kota, di tingkat provinsi, maupun di tingkat pusat.

\section{Sistem Informasi Rekam Medis}

tepat. Secara garis besar sistem informasi rekam medis memungkinkan pengguna dapat melakukan pengisisan, penyimpanan, memanggil ulang, mentransmisikan dan memanipulasi / mengolah data pasien secara spesifik baik perindividu atau kelompok, termasuk data klinis, administrasi dan demografi, sehingga dapat mengurangi pembiayaan operasional rumah sakit (Ery Rustiyanto,2010).

\section{Rekam Kesehatan Elektronik (RKE)}

Rekam kesehatan elektronik atau electronic medical record (EMR) juga sering disebut dengan computer based patient record (CPR) untuk menyatakan suatu sistem berbasis komputer yang dimanfaatkan untuk mengelola informasi pelayanan pasien.

\section{Web}

World Wide Web atau $W W W$ atau juga dikenal dengan WEB adalah salah satu layanan yang didapat oleh pemakai komputer yang terhubung ke internet. Web ini menyediakan informasi bagi pemakai komputer yang terhubung ke internet. Website atau situs dapat diartikan sebagai kumpulan halaman-halaman yang digunakan untuk menampilkan informasi teks, gambar diam atau gerak, animasi, suara, dan atau gabungan dari semuanya itu baik yang bersifat statis maupun dinamis yang membentuk satu rangkaian bangunan yang saling terkait dimana masing-masing dihubungkan dengan jaringan-jaringan halaman (hyperlink). Website atau situs juga diartikan sebagai kumpulan halaman-halaman yang digunakan untuk menampilkan informasi teks, gambar diam atau gerak, animasi, suara, dan atau gabungan dari semuanya, baik yang bersifat statis maupun dinamis yang membentuk satu rangkaian bangunan yang saling terkait, yang masingmasing dihubungkan dengan jaringanjaringan halaman (Simarmata, 2015 ).

\section{Database (Basis Data)}

Database merupakan sekumpulan data yang terorganisasi dalam bentuk berkas binari dalam komputer. Saat ini banyak sistem manajemen basis data yang beredar di pasaran. Misalnya Oracle, SQL Server, Sybase, dan Acces. Terdapat tiga tipe pangkalan data (basis data) yang dikenal luas saat ini, yaitu: 
1. Relational database. Tipe ini menyimpan data dalam susunan baris dan kolom yang telah ditentukan sebelumnya (seperti tabel kerja). Jenis data yang dapat disimpan dalam tipe ini meliputi mata uang, angka riil, integer, dan srting (karakter data).

2. Object-oriented database. Tipe ini menyimpan objek sebagai data. Objek bisa berupa sesuatu yang nyata atau abstrak. Objek data ini bisa dikembangkan menjadi data relasional atau tipe data tingkat lanjut, misalnya gambar, film dan suara.

3. Object-relational database. Tipe ini merupakan gabungan terbaik antara relasional dan Object-oriented database. Tipe ini bisa menyimpan dan memanfaatkan data baik dalam bentuk tradisional (mata uang, , angka riil, integer, dan srting) maupun data tingkat lanjut, misalnya gambar, film dan suara.

\section{DBMS (Database Management System)}

Database Management System (DBMS) adalah kumpulan program yang digunakan untuk mendefenisikan, mengatur dan memproses database. Sedangkan database itu sendiri esensinya adalah sebuah struktur yang dibangun untuk keperluan penyimpanan data. DBMS itu sendiri merupakan alat atau tool yang berperan untuk membangun struktur tersebut (Budi Raharjo, 2011). DBMS merupakan software yang digunakan untuk membangun sebuah sistem basis data yang berbasis komputerisasi. DBMS membantu dalam pemeliharaan dan pengolahan kumpulan data dalam jumlah besar. Sehingga dengan menggunakan DBMS tidak menimbulkan kekacauan dan dapat digunakan oleh pengguna sesuai dengan kebutuhan. Sistem manajemen basis data (DBMS) adalah suatu aplikasi perangkat lunak yang menyimpan struktur basis data, data itu sendiri, hubungan di antara data di dalam basis data, dan nama-nama formulir, jenis-jenis data, angka dibelakang desimal, jumlah karakter, nilai-nilai default, dan seluruh field lainnya (Raymond McLeod, Jr., George P.Schell, 2008).

\section{HTML (HyperText Markup Language)}

HTML (HyperText Markup Language) adalah suatu sistem untuk menambahkan dokumen dengan tabel yang menandakan bagaimana teks di dokumen harus disajikan dan bagaimana dokumen dihubungkan bersama-sama. Di dalam skema tambahan HTML terdapat kekuatan untuk membuat aplikasi-aplikasi client-server, multimedia, form, dan interaktif. HTML sebenarnya adalah dokumen ASCII atau teks biasa, yang dirancang untuk tidak tergantung pada suatu sistem operasi tertentu. Secara teknis, HTML didefinisikan sebagai Standard Generalized Markup Language (SGML). Sebuah dokumen HTML dapat dikatakan contoh sebuah dokumen SGML. SGML berasal dari GML (General Markup Language) pada IBM di akhir tahun 1960-an sebagai upaya untuk memecahkan beberapa problem mengangkut dokumen-dokumen pada sistem komputer yang berbeda (Moh. Sulhan, 2006).

Database Management System (DBMS) merupakan sistem yang secara khusus dibuat untuk memudahkan pemakai dalam mengelola basis data. sistem ini dibuat untuk mengatasi kelemahan sistem pemrosesan yang berbasis berkas. Pada pendekatan yang berbasis berkas, umumnya perancangan sistem didasarkan pada kebu-tuhan individual pemakai, bukan berdasarkan kebutuhan sejumlah pemakai. Setiap kali terdapat kebutuhan baru dari seorang pemakai, kebutuhan segera diterjemahkan ke dalam program komputer. Akibatnya, kemungkinan data yang sama juga terdapat pada berkas-berkas lain yang digunakan oleh program aplikasi lain (Abdul Kadir, 2003).

\section{PHP (Hypertext Preprocessor)}

PHP (Hypertext Preprocessor) merupakan skrip yang bersifat server site dimana proses pengerjaan skripnya berlangsung di server. Dengan menggunkan PHP maka perawatan suatu situs Web akan menjadi lebih mudah. PHP pertama kali ditemukan oleh Rasmus Lerdoff. Penulisan skrip PHP tersebut dengan cara disisipkan pada HTML. PHP merupakan bahasa pemograman yang digunakan untuk 
membangun aplikasi-aplikasi berbasis Web khususnya aplikasi Web yang bersifat dinamis (Moh. Sulhan, 2006).

\section{Dreamweaver}

Dreamweaver adalah sebuah editor profesional yang menggunakan HTML untuk mendesain Web secara visual dan mengelola situs atau halaman Web. Dreamweaver merupakan software utama yang digunakan oleh desiainer Web dan programer Web untuk mengembangkan suatu situs Web. Dreamwever memiliki ruang kerja, fasilitas, dan kemampuan yang mampu meningkatkan produktivitas dan efektivitas, baik dalam desain maupun pembuatan situs Web. Dreamweaver memberikan fasilitas editing HTML secara visual, serta memberikan berbagai fasilitas dan teknologi pemograman Web terkini, seperti HTML, CSS, dan JavaScript. Selain itu, aplikasi ini juga memungkinkan editing JavaScript, XML, dan dokumen teks lainya secara langsung, serta mendukung pemograman Script ServerSide seperti PHP, Active Server Page (ASP), ASP.NET, ASP JavaScript, ASP VBScript, ColdFusion, dan Java Server Page (Elcom, 2013).

\section{METODELOGI PENELITIAN}

\section{Kerangka Berpikir}

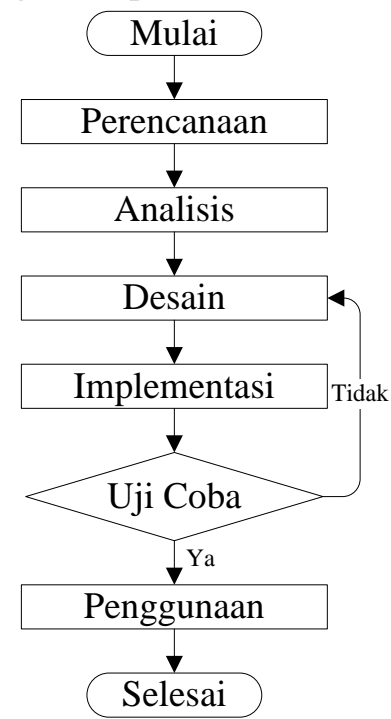

\section{Gambar 1 Kerangka Berpikir Metode Penelitian}

Metode penelitian yang digunakan untuk Perancangan Sistem Informasi Rekam Medis Bebasis Web di Klinik Bersalin Sriati adalah siklus hidup pengembangan sistem (Systems Development Life Cycle-SDLC) atau sering kali disebut sebagai pendekatan air terjun (waterfall approach) yang meliputi tahap perencanaan, tahap analisis, tahap desain, tahap implementasi, dan tahap penggunaan.

\section{Diagram Konteks}

Diagram konteks merupakan diagram paling atas dari sistem informasi yang menggambarkan proses-proses yang terjadi pada sistem dalam bentuk diagram alir data (DAD). Untuk menyediakan berbagai informasi akan dijelaskan tahapan-tahapan proses melalui penggambaran diagram konteks, yaitu:

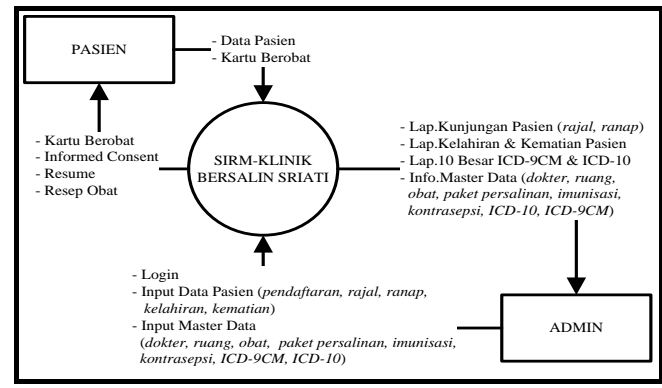

\section{Gambar.2 Diagram Konteks}

\section{Perancangan Basis Data (Database)}

Perancangan basis data bertujuan untuk memudahkan dalam penyimpanan, perubahan, dan pembacaan data. Dalam merancang basis data, perlu mendefinisikan data yang diperlukan oleh sistem. Perancangan basis data pada Sistem Informasi Rekam Medis Berbasis Web di Kinik Bersalin Sriati adalah dengan nama basis data "Klinik", yang terdiri dari 17 Tabel.

\section{Perancangan Dialog Antar Muka}

Perancangan dialog antar muka merupakan rancang bangun dari dialog antara pemakai sistem dengan komputer. Dialog ini dapat terdiri dari proses memasukkan (input) data ke sistem, menampilkan output informasi kepada pemakai atau dapat keduanya Salah satu menu yang digunakan untuk perancangan dialog antar muka penelitian ini adalah pull-down menu. 
1 Tampilan Halaman Login

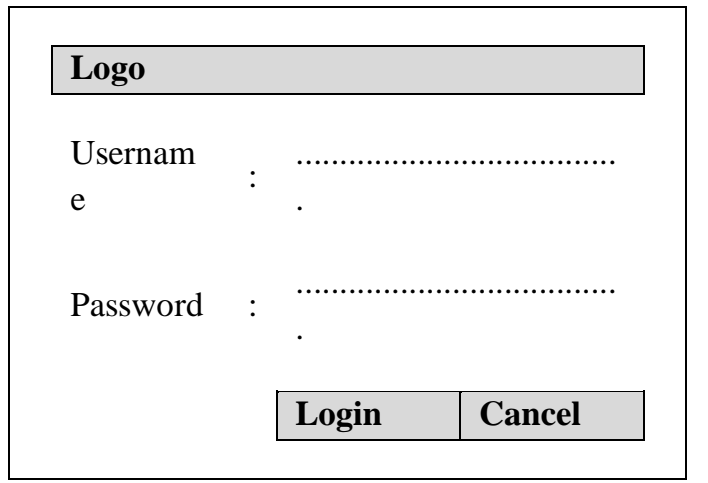

Gambar 3 Tampilan Halaman Login

2 Form Pendaftaran Pasien

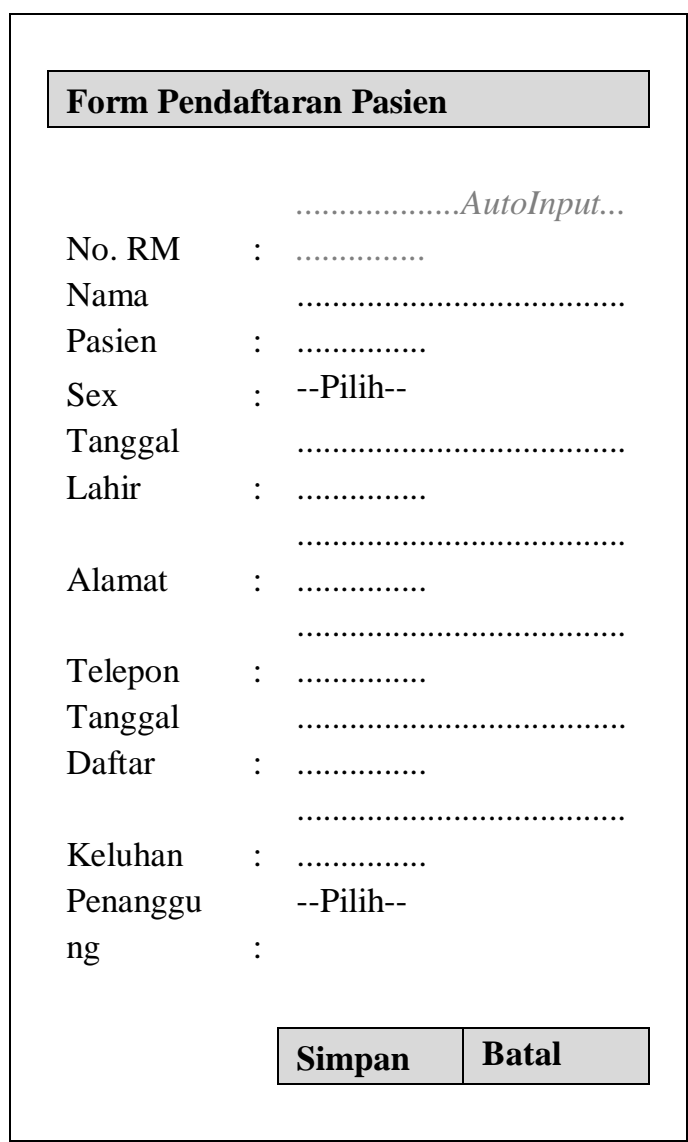

Gambar 4. Form Pendaftaran Pasien

\section{Tahap Implementasi}

Ditahapan ini merupakan kegiatan untuk mengimplementasikan rancangan yang telah disusun agar dapat diwujudkan, yaitu dengan menginstal sistem supaya siap dioperasikan.

\section{Tahap Penggunaan}

Setelah sistem diimplementasikan dan telah berhasil diuji coba, maka sistem dapat digunakan. Penggunaan sistem dilakukan dengan melakukan sosialisasi kepada petugas rekam medis di Klinik Bersalin Sriati.

\section{IMPLEMENTASI SISTEM}

Implementasi sistem merupakan penerapan dan pengujian bagi sistem berdasarkan hasil analisis dan perancangan yang telah dilakukan pada bab III. Pada bab IV ini merupakan implementasi hasil rancangan menjadi Sebuah Sistem Informasi Rekam Medis Berbasis Web di Klinik Bersalin Sriati Kota Sungai Penuh - Jambi.

\section{Antar Muka Sistem (Interface) Tampilan halaman login}

Untuk halaman login dapat diakses melalui alamat http://localhost/klinik pada web $b \bowtie$ wser maka akan tampil halaman login, kemudian admin (petugas rekam medis) melakukan login dengan mengisikan username dan password. username dan password . fungsi dari halaman ini adalah untuk dapat masuk ke halaman utama dan menggunakan fasilitas yang ada didalamnya, seperti yang terlihat pada gambar berikut ini:

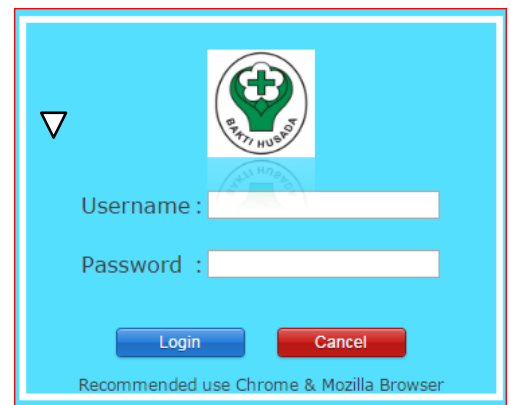

Gambar 5 Tampilan Halaman Login

\section{Tampilan Halaman Utama dan Menu}

Index halaman pada browser menunjukan halaman utama (beranda, profil, informasi, database, logout) dan menu (pendaftaran, rawat jalan, rawat inap, rekam medis, laporan pdf, laporan excel, statistik klinik, master data, manajemen user, setting). 


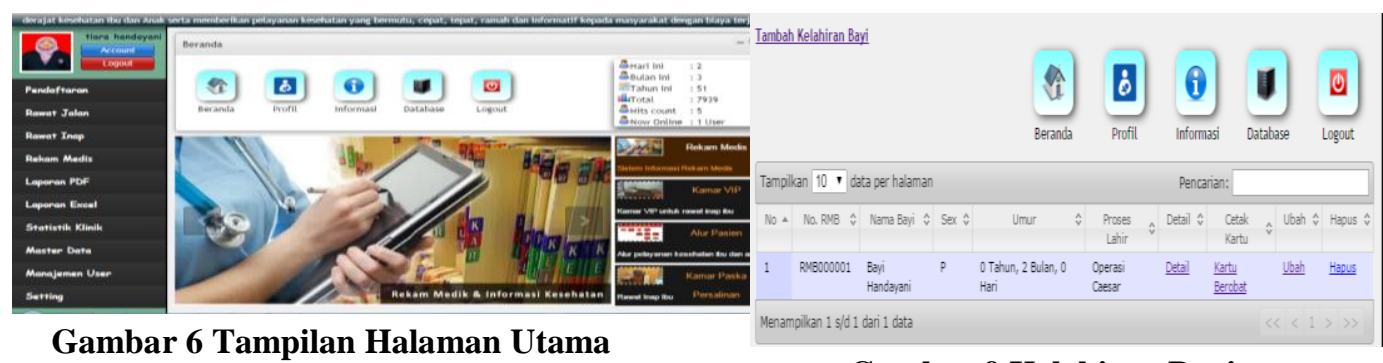

Gambar 6 Tampilan Halaman Utama

Tampilan Pendaftaran Pasien

Jika ada pasien ibu atau bayi yang ingin mendapatkan pelayanan kesehatan, maka user akan memilih menu tambah pasien dan mengisikan data pasien pada "Form Pendaftran Pasien". Pada menu pendaftaran pasien terdapat 4 opsi, yaitu detail, kartu berobat, ubah dan hapus.

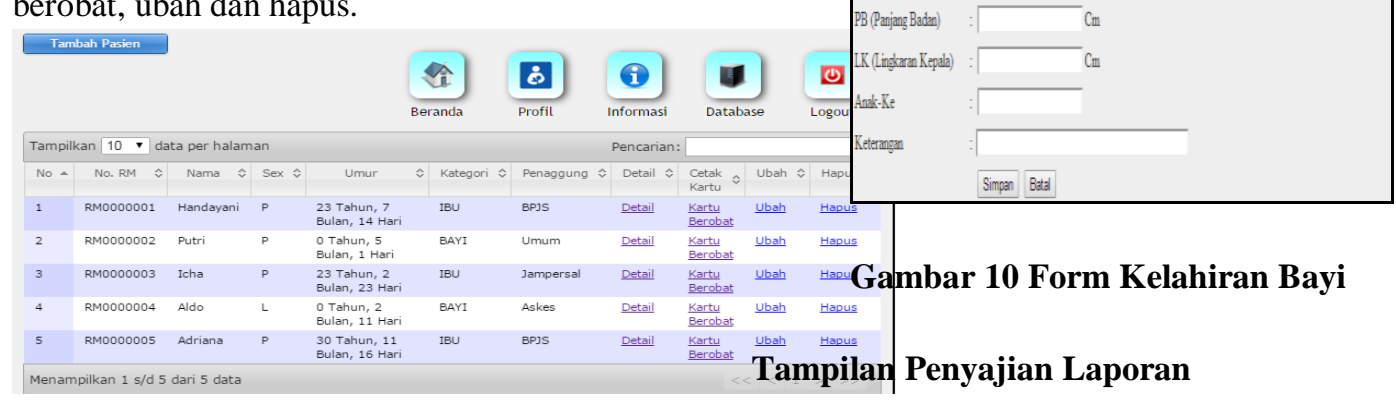

Gambar 7 Pendaftaran Pasien

Pada tampilan penyajian laporan, user dapat mengakses pada menu laporan yang terdiri dari format PDF dan Excel. Pilih

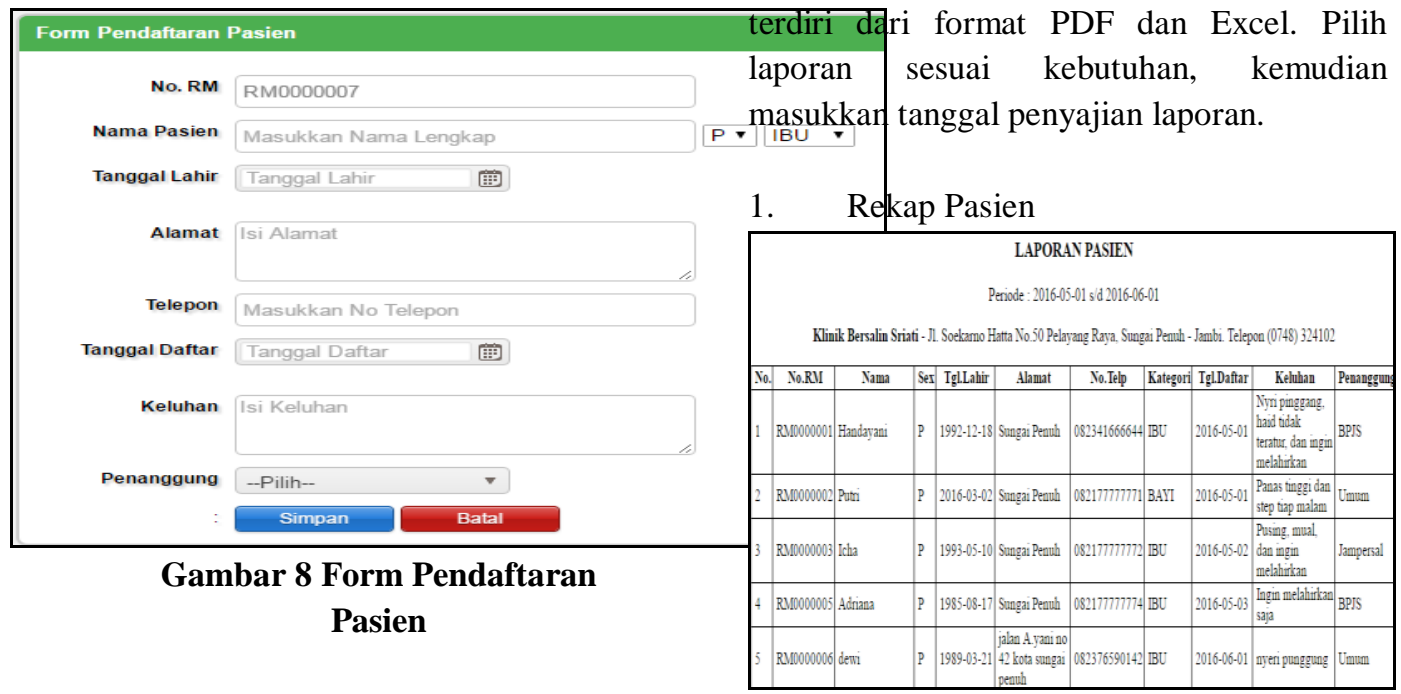

\section{Tampilan Kelahiran Bayi}

Jika ada kelahiran bayi, maka user

Gambar 11 Rekap Pasien akan memilih menu tambah kelahiran bayi dan mengisikan data bayi pada "Form Kelahiran Bayi". Pada menu kelahiran bayi terdapat 4 opsi, yaitu detail, kartu berobat, ubah dan hapus. 
2. Rekap Rawat Jalan

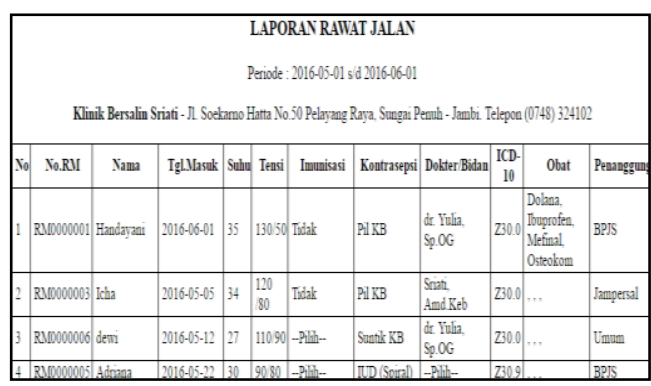

Gambar 12 Rekap Rawat Jalan

3 Rekap Rawat Inap

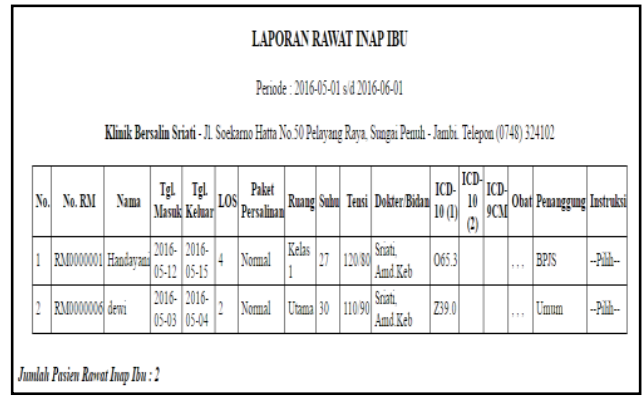

\section{Gambar 13 Rekap Rawat Jalan}

4 Laporan 10 Besar Tindakan Berdasarkan Kode ICD 9 CM

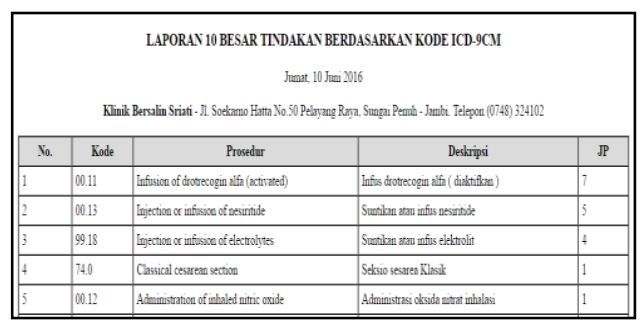

\section{Gambar 14 Rekap Rawat Jalan}

5 Laporan 10 Besar Diagnosa Berdasarkan Kode ICD 10

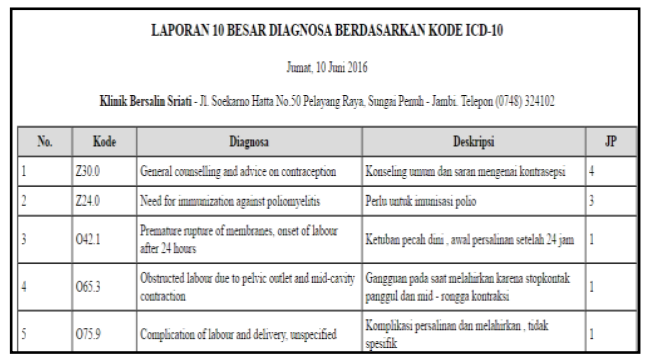

Gambar 15 Rekap Rawat Jalan
6 Tampilan Statistik Klinik

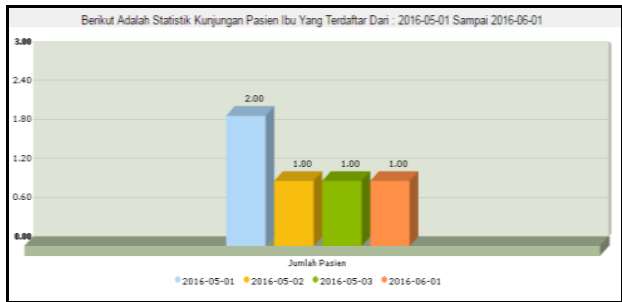

Gambar 16 Rekap Rawat Jalan

\section{SIMPULAN DAN SARAN \\ Simpulan}

1 Perancangan Sistem Informasi Rekam Medis Berbasis Web di Klinik Bersalin Sriati Kota Sungai Penuh - Jambi dapat digunakan secara terkomputerisasi oleh petugas Klinik Bersalin Sriati.

2 Dengan adanya Sistem Informasi Rekam Medis ini antrian pasien pada saat registrasi, khususnya rawat jalan dapat dikurangi.

3 Sistem Informasi Rekam Medis Berbasis Web di Klinik Bersalin Sriati memudahkan petugas rekam medis pada saat pencatatan rekam medis pasien rawat inap, pencatatan data dokter, pencatatan data ruang, pencarian kode prosedur ICD $9 \mathrm{CM}$, dan pencarian kode diagnosa ICD 10 serta pembuatan informed consent pasien.

4 Sistem Informasi Rekam Medis Berbasis Web di Klinik Bersalin Sriati Kota Sungai Penuh - Jambi menghasilkan laporan rekap kunjungan data pasien, laporan kelahiran bayi, laporan kematian ibu dan bayi, dan laporan- laporan administrasi yang dibutuhkan pihak manajemen untuk pengambilan keputusan dan informasi rekam medis pasien untuk klaim asuransi. 
Saran

Sistem Informasi Rekam Medis Berbasis Web Klinik Bersalin Sriati Kota Sungai Penuh - Jambi ini dapat dikembangkan dengan menambahkan beberapa sistem lain seperti IGD, gizi, farmasi, kamar operasi, dan laboratorium sehingga terbentuk sistem informasi manajemen yang lengkap dan terintegrasi.

\section{DAFTAR PUSTAKA}

[1] Akbar, Aidil., 2016. Perancangan Sistem Informasi Rekam Medis Rawat Inap Berbasis Web di RSUD Solok Selatan. Badung: Skripsi Fakultas Ilmu Kesehatan Sains Dan Teknologi Universitas Dhyana Pura Bali.

[2] Brady,M., \& Looman, J. 2010. Exploring the use of entity relationship diagramming as a technique to support grounded theory enquiry, Bradfold: emerald group publishing.

[3] Ekowati, Y., 2003. Rancangan Basis Data Informasi Morbiditas Yang berbasis Komputer di Balai Pengobatan Umum (BPU) Puskesmas Petarukan Kecamatan Petarukan Kabupaten Pemalang. Semarang: Skripsi Fakultas Kesehatan Masyarakat Universitas Diponegoro.

[4] Elcom, 2013. Seri Belajar Kilat Dreamweaver CS6. Yogyakarta: Andi Offset.

[5] Erkadius, dr., M.Sc., 2010. Manajemen Informasi Kesehatan I Bagian I. Padang: Apikes Iris.

[6] Erkadius, dr., M.Sc., 2010. Manajemen Informasi Kesehatan IV. Padang: Apikes Iris.

[7] Frasis, Aria., 2011. Sistem Informasi Rawat Inap dan Rawat Jalan di Rumah Bersalin Bidan Illa. Bandung: Skripsi Fakultas Ilmu Komputer Universitas Komputer Indonesia.

[8] Gibony JR.1991. Medical Records Principle Of Hospotal Administration. NewYork: GP Putnam's Sons.
[9] Kadir, Abdul., 2003. Pengenalan Teknologi Informasi. Yogyakarta: Andi Offset.

[10] Madcoms., 2013. Kupas Tuntas Adobe Dreamweaver CS6 dengan Pemograman $P H P$ \& $M y S Q L$. Yogyakarta: Andi Offset.

[11] McLeod, Raymond, Jr., P.Schell George., 2008. Sistem Informasi Manajemen, Edisi 10. Jakarta: Selemba Empat.

[12] Permenkes No 028 Tahun 2011. Sistem Informasi Manajemen Rumah Sakit. Jakarta: Kementrian Kesehatan.

[13] Permenkes No 147 Tahun 2010. Perizinan Rumah Sakit. Jakarta: Kementrian Kesehatan.

[14] Permenkes No 269 Tahun 2008. Rekam Medis. Jakarta: Kementrian Kesehatan.

[15] R. Hatta, Gemala., 2012. Pedoman Manajemen Informasi Kesehatan Disarana Pelayanan Kesehatan. Jakarta: Universitas Indonesia (UIPress).

[16] Raghib, Nuruddin., 2013. Pengertian dan Definisi Web http://raghibnuruddin217.blogspot.com [diakses 27 februari 2016].

[17] Raharjo Budi., 2011. Belajar Kilat Otodidak Membuat Database Menggunakan MySQL. Bandung: Informatika Bandung.

[18] Rustiyanto, Ery., 2010. Sistem Informasi Manajemen Rumah Sakit yang Terintegrasi. Yogyakarta: Gosyen Publishing.

[19] Simarmata. Janner (2010). Rekayasa Perangkat Lunak. Andi Offset. Yogyakarta.

[20] Sulhan. Moh., 2006. Pengembangan Aplikasi Barbasis Web dengan PHP dan ASP. Malang: Gava Media.

[21] Supardi Ir.Yuniar. 2013. Semua Bisa Menjadi Programmer Visual Basic 2010. Elex Media Komputindo.Jakarta.

[22] Supardi, Yuniar, Ir., 2013. Semua Bisa Menjadi Programer Visual Basic 2010 Case Study. Jakarta: Elex Media Komputindo. 
[23] UU RI No 44 Tahun 2009. Rumah

Sakit. Jakarta: Kementrian Kesehatan.

[24] Wahana Komputer. 2010. Panduan

Belajar MySQL Database Server.

Media Kita. Jakarta Selatan.

[25] Wahyu, 2004. Sistem Informasi

Manajemen Yogyakarta. UPP (Unit

Penerbit dan Percetakan) AMP YKPN 